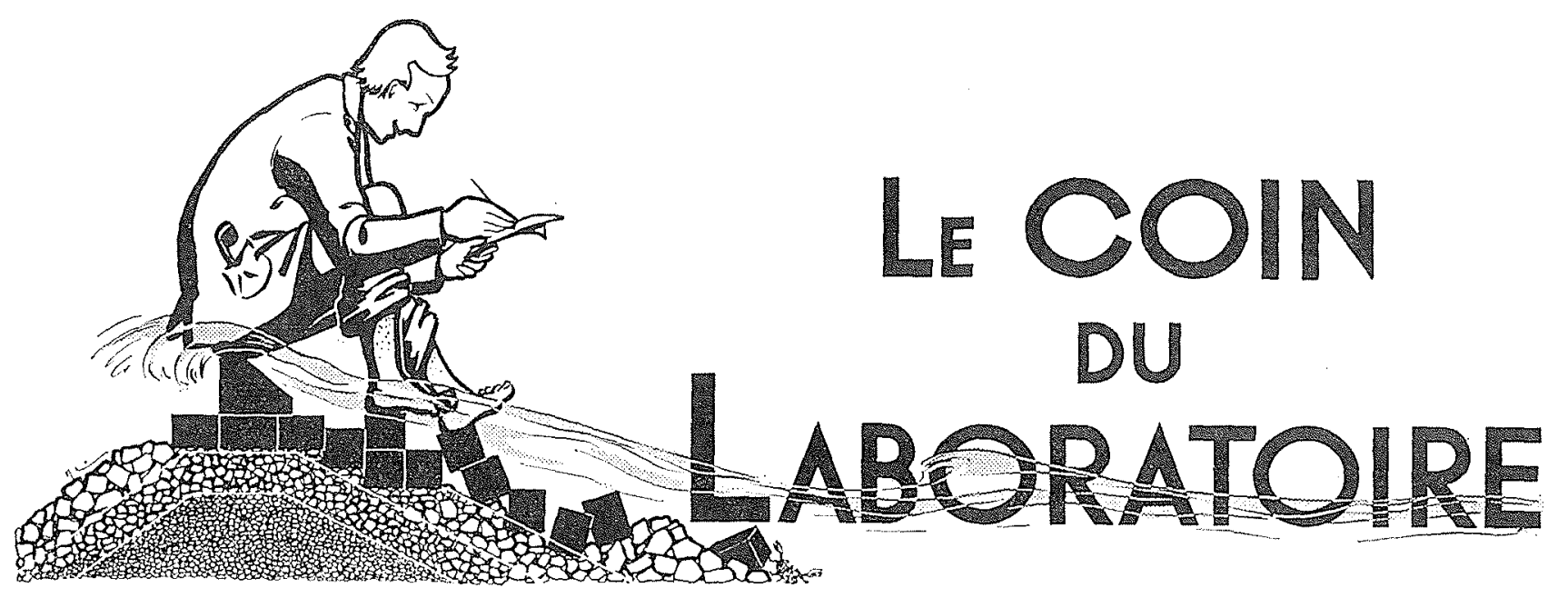

\title{
Débitmètre à contraction pour les mélanges d'eau et de matériaux
}

English text, p. 64 .

\begin{abstract}
Difficulless de la mesure dn débil de mixlure en conduite. Principe de l'appareil : crétion d'un jet contraté it lextremité de la conduite, el mesure de la surpression résullante dans une section amont voisine. L'ilalonnage de l'appareil et son interpretation. Sa gamme d'ulilisation.
\end{abstract}

Difficulties of the measurement of a solid discharge in a pipe. Principle of the instrument: creation of a contracted jet at the pipe outlet and measurement of the resulting overpressure in a nearby npstream cross-section. The calibration of the inslinment and its interprelation. Ils atses.
Le Transport solide pose à l'Ingénieur $\mathrm{Hy}$ draulicien toute une série de problèmes qui sont certainement parmi les plus difficiles de ceux qu'il est amené à résoudre. Chacun sait, par exemple, combien la présence de matériaux solides dans l'eau complique l'évolution, la vie d'un cours d'eau, d'un canal ou d'un littoral. Aspect assez différent, et sensiblement moins complexe de ce trìs vaste ensemble, le transport hydraulique des matériaux solides en conduite fait l'objet d'applications industrielles qui ne sont certes pas nouvelles, mais qui sont probablement susceptibles de très larges développements. Depuis quelques années, le Laboratoire Dauphinois d'Hydraulique s'est vu confier à plusicurs reprises l'étude détaillée d'installations de ce genre : transports de schlamms dans les mines, et transport de produits de dragage en particulier.

Dans le cadre de l'étude d'ensemble qui s'est avérée indispensable pour dégager les traits fondamentaux de ce type de phénomines, nous ayons dû progressivement mettre au point toute une série de dispositifs expérimentaux relativemont nouveaux et adaplés aux conditions d'essai tres particulièes qui nous étaient imposées par lat nature mème de nos recherches.

C'est l'un de ces dispositif's que nous nous proposons de présenter ci-dessous.

\section{Mesure DEs DébITS EN MATURE}

La mesure du débit en eau claire est aujourd'hui une opération courante qui bénéficie, dans les Laboratoires d'Hydraulique, d'une très longue expérience; les dispositifs utilisés à cet effet: déversoirs, Venturi, sont bien connus, mais ils exigent toujours,'néanmoins, un réglage minutieux et un étalonnage très précis.

Les choses se compliquent singulierement quand, au lieu d'eau claire, on se trouve en présence d'un mélange intime, d'une « mixture » 
d'eau et de particules solides dont le comportement réciproque est essentiellement capricieux et les liens infiniment fragiles.

Alors que l'installation d'essai est toule entière conçue et exploitée avec le souci permanent et dominant de s'assurer des régimes de fonctionnement parfaitement définis et invariables, on ne peut pas admettre qu'un appareil de mesure quelconque vienne fausser, même léggèlement, des conditions si difficilement obtenues.

A première vue, la méthode la plus simple et la plus précise consisterait dans l'emploi d'une capacilé jaugée. Cette méthode n'est malheureusement pas toujours utilisable. Pour avoir une précision suffisante, il faut, en effet, réaliser un prélèvement correspondant à un temps de fonctionnement de plusieurs secondes. Pendant cette période, le bassin d'aspiration de la pompe cessera alors d'être alimenté sur une installation en circuit ferné.

Pour les forts débits, it en résultera une modification progressive du point de fonctionnement au cours du prélèvement.

Pour une vitesse moyenne de $3 \mathrm{~m} / \mathrm{s}$, une conduite de $60 \mathrm{~m}$ de longueur est parcourue par la mixture en $20 \mathrm{~s}$. Si le temps de prélèvement est de 5 s, on tendra, à la fin du prélèvement, à avoir de l'eau claire sur le quart du circuit.

Pour atténuer cet effet, on peut évidemment intercaler sur le circuit un bassin tampon de capacité suffisante, et d'ailleurs le bassin d'aspiration de la pompe réalise toujours plus ou plus ou moins cet effet tampon.

Cependant, un bassin suffisamment grand pour permettre la mesure par capacité jaugée devient gènant au moment de l'arrêt de l'installation et impose des temps de mise en régime exagérément longs.

II nous a done semblé ntile de mettre au point un dispositif de mesure instantané qui puisse. de plus être utilisé également sur les installalions industrielles.

\section{Privche de L'APPARETr}

Le dispositif employé consiste à crécr une contraction du jet à la sortie de la conduite. A une distance suffisamment courte à l'amont pour pouvoir négliger les pertes de charge, on aura dans la conduite une pression correspondant à la différence entre les hauteurs cinétiques dans la section de sortie et dans la section de mesure.

\section{$\mathrm{Si}$ :}

Q est le débit à mesurer;

S la section de la conduite; s la section contractée à la sortie de la conduite; $\mathrm{H}=\frac{\Delta \mathrm{P}}{\bar{\omega}}$ la dénivelée lue au manomètre monté sur la prise de pression;

on aura:

$$
\frac{\Delta P}{\pi}=\frac{Q^{2}}{2 g}\left(\frac{1}{s^{2}}-\frac{1}{\mathrm{~S}^{2}}\right)
$$

En se référant à la vitesse moyenne dans la conduite, on aura:

$$
\mathrm{H}=\frac{\Delta \mathrm{P}}{\pi}=\frac{\mathrm{V}^{2}}{2 g}\left[\left(\frac{\mathrm{s}}{\mathrm{s}}\right)^{2}-1\right]
$$

En appelant $k$ le rapport de sections $\frac{s}{S}$ :

$$
\frac{\Delta \mathrm{P}}{\bar{\pi}}=\left(\frac{1}{\mathrm{~K}^{2}}-1\right) \frac{\mathrm{V}}{2 y}
$$

Avec les dispositifs réalisés, cette formule se trouve bien vérifiéc et peut tenir lieu de courbe d'étalonnage en eau claire. Pour que cette condition soit réalisée, il faut évidemment que le tracé du convergent empèche le décollement de

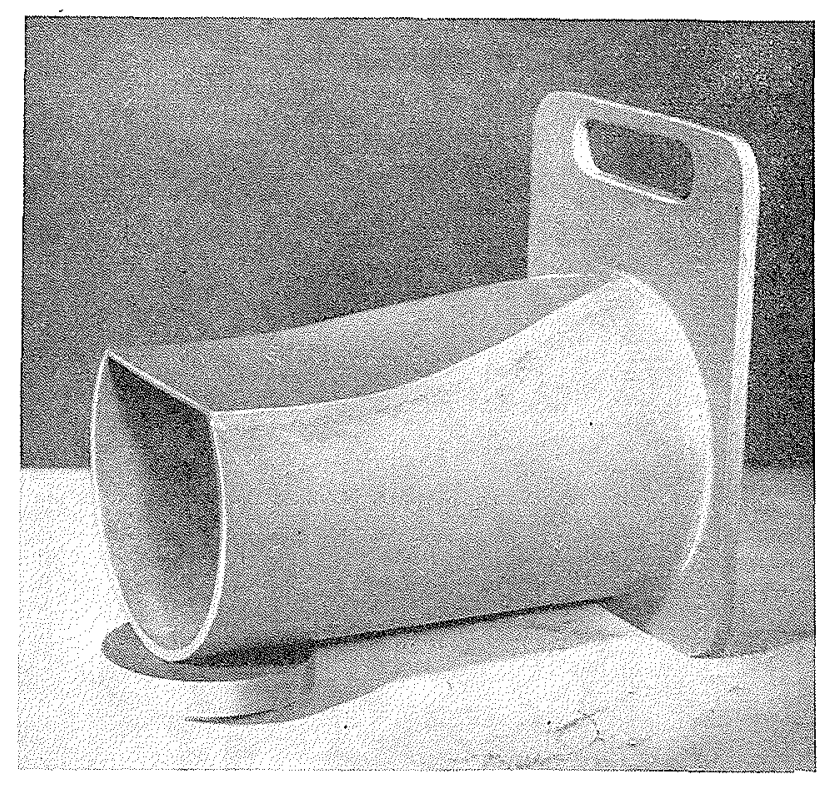

FIG. 1. - Le débitmètre à contraction. the contraction flow-meter.

la veine à la sortie. L'appareil affecte la forme d'un sifflet (voir fig. 1), dont la réalisation est relativement facile. La figure 2 donne en variables relatives le plan d'un sifflet ayant pour rapport de contraction $K=0,60$.

La figure 3 donne la valeur mesurée pour $\frac{\mathrm{H}}{\mathrm{V}^{2}}$ 
pour diver's sifflets réalisés et étalonnés en fonction de $\frac{1}{2 g}\left(\frac{1}{\mathrm{~K}^{2}}-1\right)$.

On obtient bien une droite à $45^{\circ}$. Ce résultat a

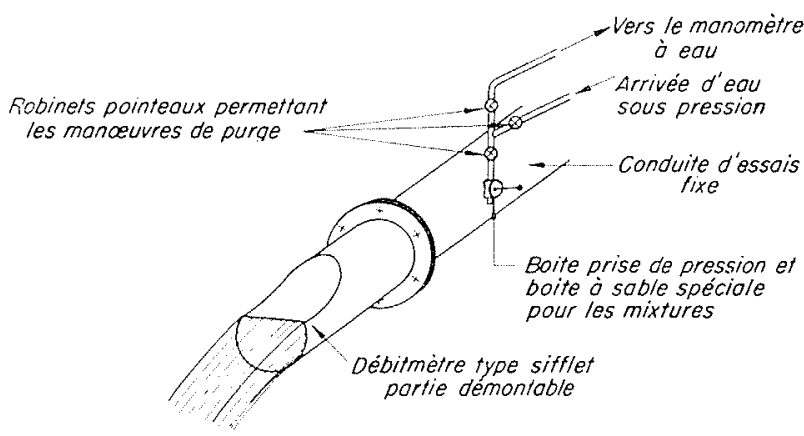

Oebitmètre pour une conduite de bose

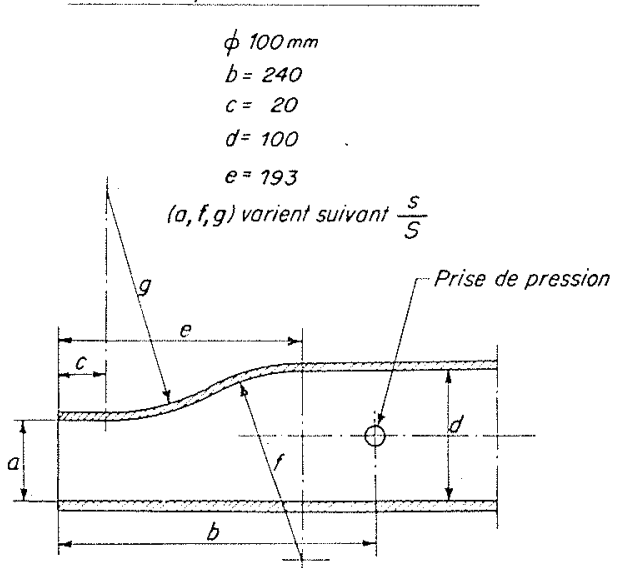

Fig. 2. - Schéma du débitmètre à contraction. Diagramm of contraction flow-meter.

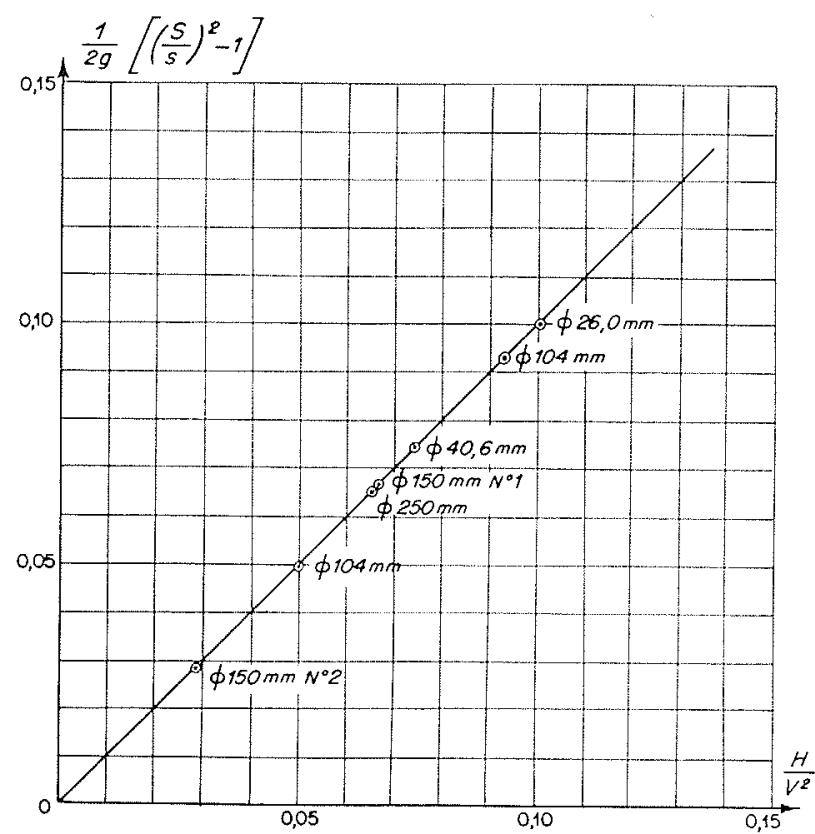

FIa. 3. - Valeurs du coefficient. K pour différents débitmètres à contraction.

$\mathrm{K}$ coefficient values for various contraction flow-meter. été obtenu grâce à des ètalonnages effectués en eau claire au déversoir type Rehbock ou à la capacité jaugée, suivant l'importance des débits réalisés.

La prise de pression est analogue à celles employées pour les mesures de perte de charge. Le manomètre est constitué par un simple tube de verre fixé le long d'une règle graduée. On peut le remplacer ou le doubler par un manomètre enregistreur.

\section{ETALONNAge DU DÉBITMEtTRE EN MIXTURE}

Nous avions déjà été amenés à utiliser cet appareil au cours d'études antérieures et nous avions admis, sous réserve de vérification, que l'étalonnage établi en eau claire restait valable en mixture, à condition de corriger l'indication du débitmètre en divisant la hauteur d'eau claire par la densité de la mixture (concentration de transport).

Nous avons voulu vérifier ce point et, pour cela, nous avons entrepris une campagne d'essais d'étalonnage sur notre installation de refoulement en conduite de $40 \mathrm{~mm}$ de diamètre.

L'installation fonctionnait en circuit ouvert et le débit était vérifié à la capacité jaugée. Un dispositif avec tapis roulant assurait l'alimentation en matériaux à débit solide constant.

Nous avons effectué deux séries d'essais :

- Avec le débitmètre en position horizontale; - Avec le débitmètre en position verticale.

\section{Etalonnage DU DÉBITMETRE \\ TN POSITION HORIZONTALE AVEC TRANSPORT DE MIXTURES}

Le débitmètre d'essais avait été étalonné au préalable en eau claire. La figure 4 donne les résultats de ces essais.

Les essais en mixture ont été effectués avec plusieurs types de matériaux, de dimensions et de densité différentes et à des concentrations et à des débits différents.

\section{a) Sable de Loire :}

Mélange de sables de diamètre moyen $d n=1,50 \mathrm{~mm}$. Les concentrations étudiées, exprimées en volume vrai en $\%$, ont varié de $3,7 \%$ à $19,70 \%$ pour des vitesses allant de $1,40 \mathrm{~m} / \mathrm{s}$ à $2,50 \mathrm{~m} / \mathrm{s}$.

\section{b) Sable de Barbière :}

Sable de diamètre moyen $d n=0,10 \mathrm{~mm}$, de densité 2,65 , pour une concentration de $20 \%$ en volume vrai. 


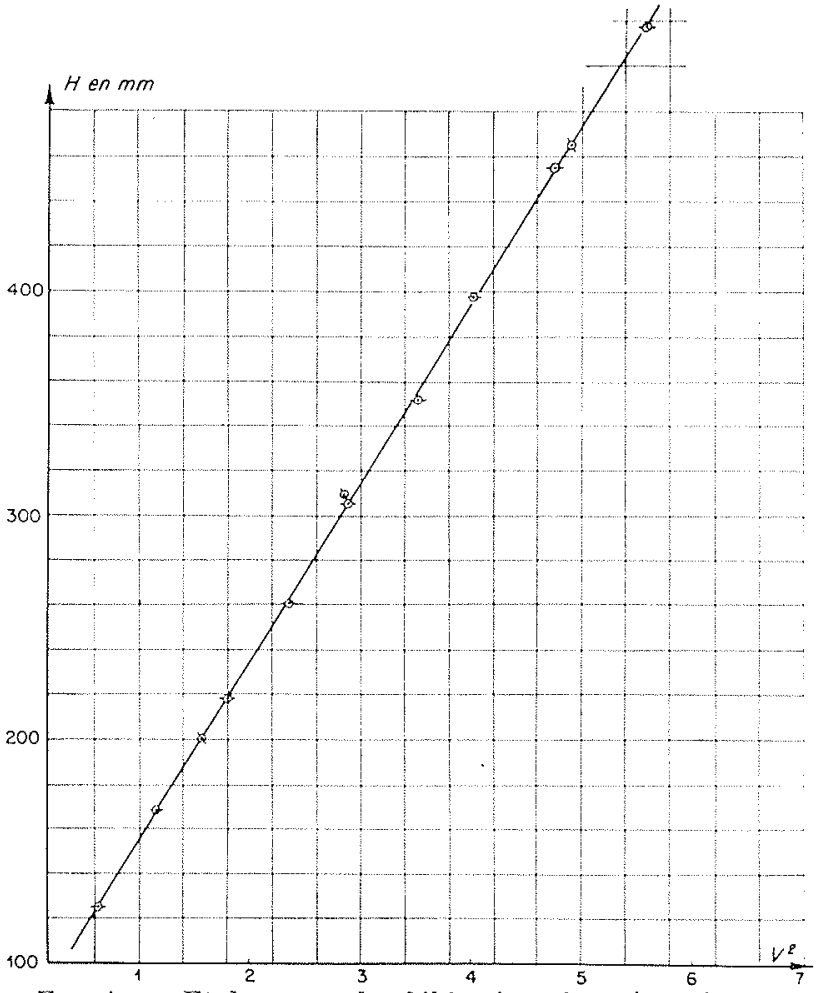

Fig. 4. - Etalonnage du débitmètre à contraction en eau claire $(\varnothing=40 \mathrm{~mm})$.

Clean water calibration of contraction flow-meter.

c) Gravillons du Rhóne:

Diamètre moyen $d n=5 \mathrm{~mm}$, densité 2,65 , concentrations étudiées $3,98 \%$ à $16,90 \%$ en volume vrai.

d) Suie :

Diametre moyen $d n=0,050 \mathrm{~mm}$, densité 2,24, concentrations étudices 5,51 à $5,95 \%$ en volume vrai.

e) Copeanx de fonte:

Diamèlre moyen $d n=4 \mathrm{~mm}$, densilé 6,50 , concentration $3,14 \%$ en volume vrai.

Les résultats de ces essais sont donnés par la figure 5 .

Nous avons remarqué pendant ces essais, pour les vitesses correspondant au régime de dépôt dans la conduite de refoulement, que les pressions mesurées par le manomètre étaient fonction à la fois de la hauteur du dépôt dans la conduite et du débit de mixture.

\section{Etralonnage dU DÉbitmètre EN POSITION VERTICALE} AVEC TRANSPORT DE MIXTURE

Nous arons effectué des essais semblables avec le débitmètre en position verticale à l'extré-

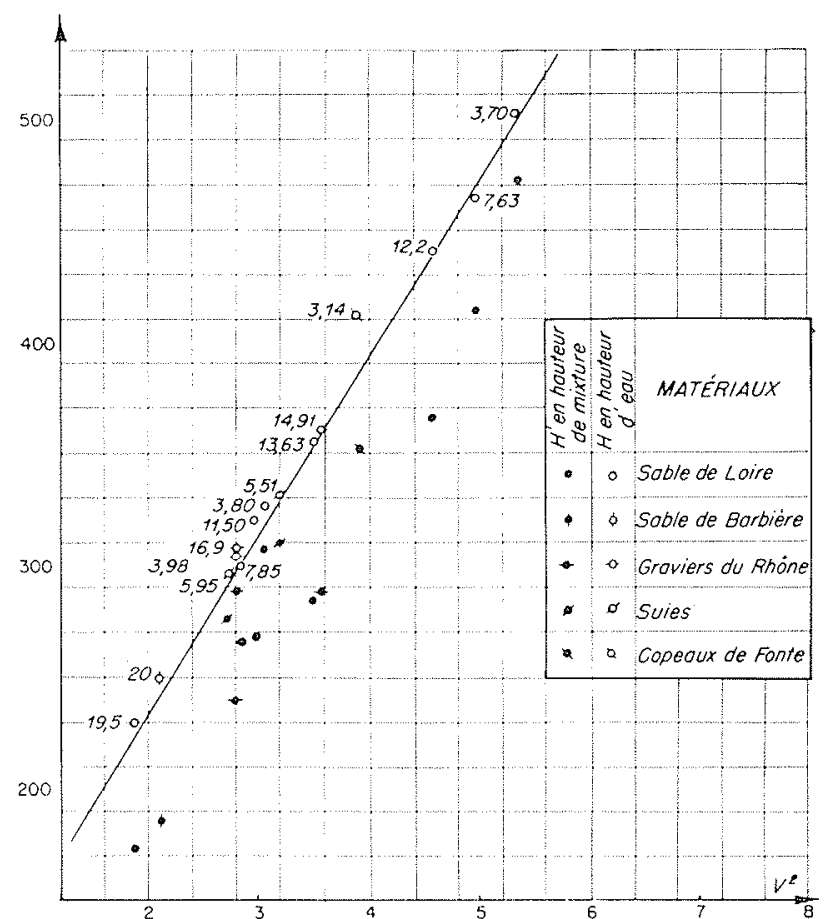

Frg. 5. - Etalonnage du débitmètre à contraction en conduite horizontale $(\varnothing=40 \mathrm{~mm}$ ).

Horizontal pipe calibration of contraction flow-meter.

mité d'un col de cyğne pour éviter tout dépòt dans la partie amont du débitmetre.

Ces essais ont été effectués avec des sables de

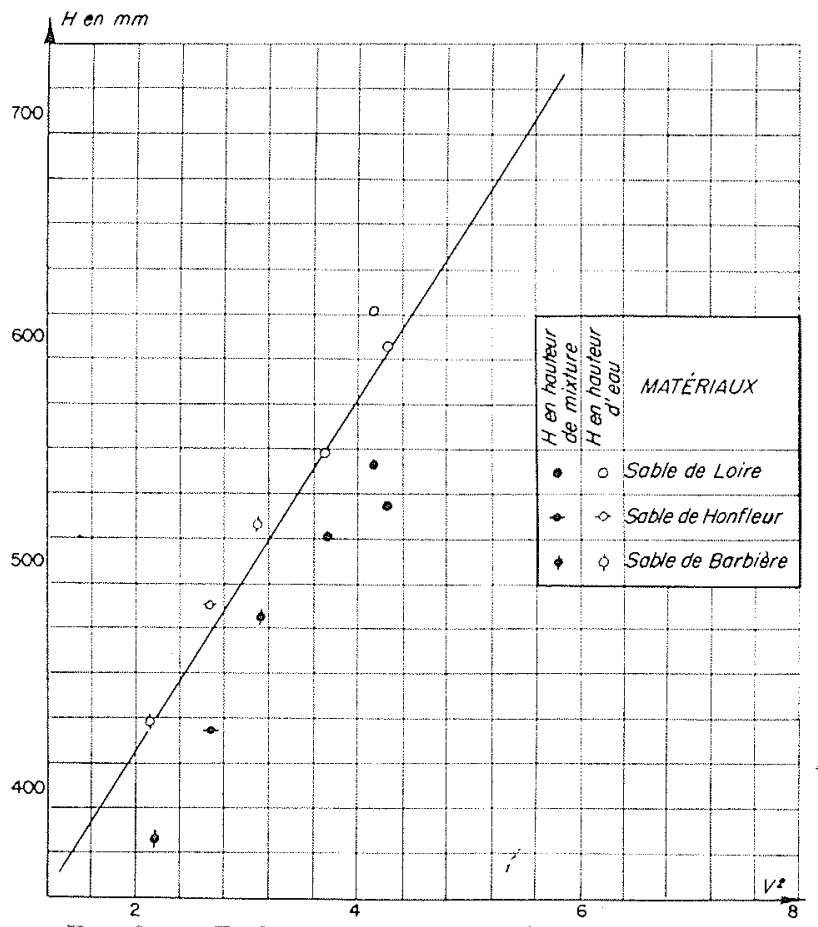

Fia. 6. - Etalonnage du débitmètre à contraction en conduite verticale $(\varnothing=40 \mathrm{~mm})$.

Vertical pipe calibration of contraction flow-meter. 
Loire, des sables de Honfleur et du sable de Barbière, caractérisés dans le paragraphe précédent.

Les résultats de ces essais sont donnés par la figure 6 .

\section{INTERPRÉTATION DES RÉSULTATS D'ESSAIS}

Les hauteurs lues au manometre en hauleur d'eau claire au cours des essais sont exprimées en fonction de $\mathrm{V}^{2}(\mathrm{~V}$ : vitesse moyenne de l'écoulement de la mixture dans la conduite). Sur les figures 5 et 6 , les points blanes correspondent aux lectures directes en hauteur d'eau claire.

On voit sur ces graphiques que, quels que soient le matériau, son diamètre el la concentration de transport, l'augmentation de pression due at rétrécissement du débitmètre reste tres peu fonction de la densité de mixture, puisque, pratiquement, tous les points d'essais viennent se placer sur la courbe d'étalonnage du débitmètre en eau claire.

Le plus grand écart enregistré correspond au transport de copeaux de fonte, qui donne une erreur de 4 o sur la vitesse moyenne de l'écoulement.

Nous avons donné également, sur les mêmes graphiques, les points d'essais (points noirs) avec les hauteurs manométriques corrigées de la densité de mixture $\mathrm{H}=\mathrm{H} / \hat{o}$ (ó étant la densité de la mixture transportée). La dispersion devient très grande et tous les points se situent alors systématiquement sous la courbe d'étalonnage en eau claire.

Quoi qu'il en soit, sans entrer dans le détail théorique du mécanisme du transport dans les débitmètres type sifflet, nous avons admis dans le cadre général des essais de transport de sable en conduite, apres les expériences que nous venons de décrire, que la courbe d'étalonnage des débitmètres en eau claire était valable également avec transport de matériaux solides, à condition de travailler avec des sables on des matériaux de densité inférienre à 3 , pour des concentrations ne dépassant pas $20 \%$ en rolume vai, dans des conditions telles qu'il n'y at aucune formation de dépôt à l'amont du sifflet et que le coefficient de contraction $K$ du sifflet soit tel que $K \geqslant 0,5$.

Il y a lieu de noter que lorsqu'il s'agit de matériaux très fins doués de proprictés plastiques, il convient de corriger l'indication lue au manomètre de la densité de mixture. Quoi qu'il en soit, nous sommes en dehors de ce cas poul les sables qui constituent la part principale des alluvions naturelles.

Nous avons également procédé à l'étalomnage du débitmètre à sifflet pour les régimes avec dépôt.

Nous ne donnerons pas ici les résultats obtenus, pour ne pas surcharger cet exposé. Iis ont

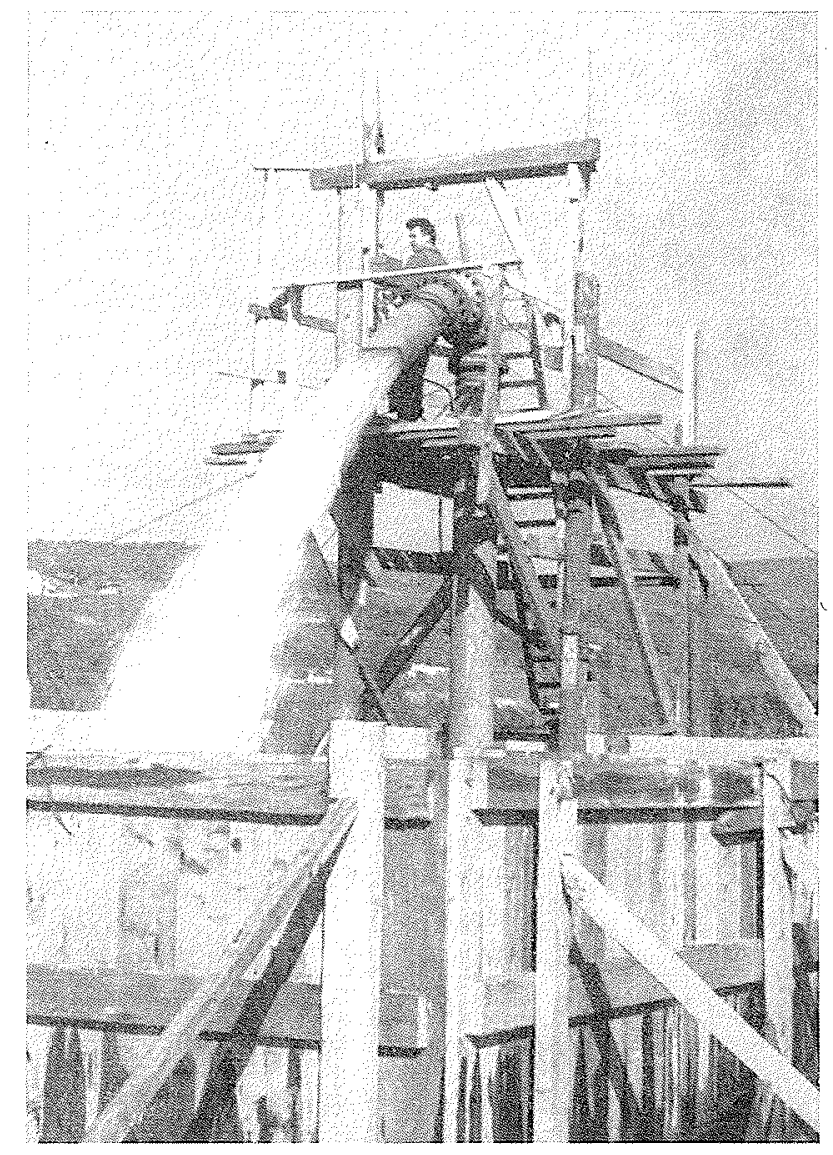

Fir. 7. - Mesures à l'installation de dragage de Donzère-Mondragon.

Measurements being carted out on Donzere-Mondragon dredging site.

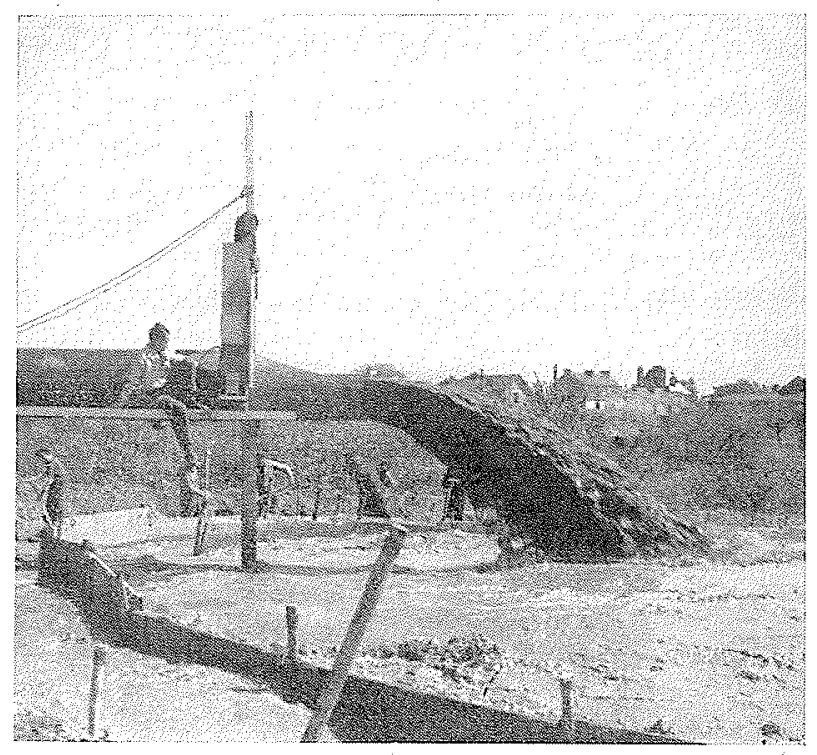

Fig. 8. - Mesures ì l'installation de dragage de Nantes.

Measurements being carried out on Nantes dredging site. 
permis d'interpréter avec succès les mesures effectuées à Nantes sur des conduites de 580 et $700 \mathrm{~mm}$ de diamètre, avec l'aide de débitmètres a contraction (fig. 7). Ces mesures ont fait l'objet d'une communication à la Société Hydrolechnigue de France par MM. Sonsin et BALLADE.

Le débitmetre à contraction a été ulilisé également avec succès à Donzère pour les essais de la drague CNR2 avec des galets dont le diametre atteignait $100 \mathrm{~mm}$ (fig. 8 ).

Pour terminer, nous préciserons que pour des sables en régime d'écoulement sans dépôt, Ia précision de la mesure des débits ou des vitesses moyennes est trés vaisemblablement supérieure $\dot{a} \pm 2 \%$.

\section{Concluston}

Concu pour sadapter aux conditions tres parliculieres de la mesure du débit dans les installations d'essais pour le transport de matériaux solides en conduite, le débitmitre à sifflet, basé sur la mesure de la pression à l'origine d'un jet contracté, s'est parfaitement comporté tout au long de nos travaux.

Il s'insere sans difficulté dans l'installation la plus complexe, sams en perturber le régime de fonctionmement.

Son montage et son démontage ne présentent ancune difficulté, son exploitation est particulierement commode.

Les épreuves tres sévères auxquelles nous l'avons sommis próalablement, les ćlalonnages lres minulieux qui ont précédé la mise en service de chacun de ses modèles, nous ont assurés que, dans une bande très large de concentration et de densité des matériaux, et sous réserve de quelques précautions élémentaires (dépôts), la précision obtenue est très satisfaisante, et au moins de $\pm 2 \%$.

Enfin, dans le tracé de ses formes, le débitmètre à sifflet résulte du double souci de respecter les exigences de l'hydraulique et de faciliter sa fabrication. La simplicité de l'appareil n'est pas, à notre avis, le moindre de ses avantages. Son utilisation avec succes, à l'échelle industrielle, sur des installations de dragage, à Donzère-Mondragon ou à Nantes, en est une lumineuse illustration. Celte faculté d'adaptation, de la part d'un appareil de laboratoire, est suffisamment remarquable pour qu'elle mérite d'être signalée.

LABORATOLE DACPHANOS D'TYDRAULRUE (Neyrpic-Grenoble.)

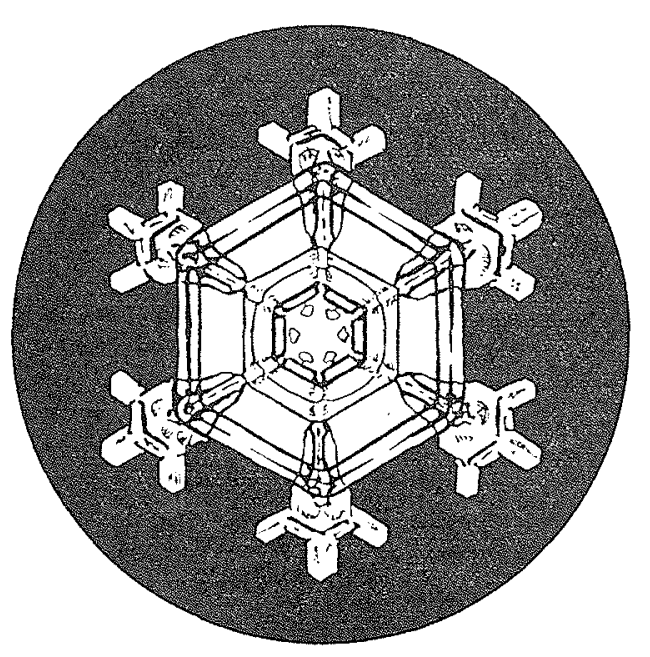




\section{LABORATORY PRACTICE}

\section{Contraction flow-meter \\ for mixtures of water and materials}

See French text p. 58 for illustrations.

The question of the transport of solids presents the Hydranlic Engineer with a whole series of problems which are certainly among the most bafhing of all those he is called upon to solve. For example, it is well-known how the presence of solids in water complicates the evolution and life of a water-course, channel or seaboard. A rather different and considerably less complex aspect of this extremely vast problem, fhe transport by water of solid materials in pipes, is the subject of industrial applications which are cortainly not new but which are probably open to considerable development. Over a period of many years, the Laboratoire Dauplinois d'Hydraulicue has, on a number of occasions, been asked to make the detailed study of installations of this type: in particular, with regard to the transport of sludge in mines and of materials obtained during dredging operations.

During our study of the entire problem as a whole (this has been found essential in order to define the fundamental characteristics of this type of phenomenon), we have in the course of time been obliged to perfect a whole series of relatively new experimental devices adapted to the special test condilions prescribed by the very nature of our research.

It is one of these devices that we propose to introduce below :

\section{MEASUREMENT OF FLOW OF MIXTURES}

The measurement of the flow of clean water is to-day a standard operation - the result of years of experience in Hydraulics Laboratories; the devices used for this purpose, such as weirs and Venturi tubes, are quite well-known but nevertheless demand careful adjustment and very accurate calibration.
However, the problem becomes singularly complicated when, instead of clean water, one is confronted with an intimate mixture of water, and solid particles, the behaviour of which vis-a-vis each other is essentially unpredictable and the bonds of which infinitely fragile.

As the principal and ever-present aim in the design and use of test installations is to ensure clearly defined and invariable operational conditions, it cannot be admitted that any measuring instrument may falsify, even if only slightly, these conditions which are so difficult to obtain.

At first sight, the simplest and most accurate method would appear to consist of the use of a calibrated tank but, unfortunately, this method is not always practicable. In order to attain a sufficient degree of precision, it is in fact necessary to take a sample corresponding to an operational period of several seconds. During this period, the pump suction tank is no longer fed in a closed circuit installation.

With high discharges, there is a progressive modification of the point of operation durings sampling:

At an average velocity of 3 metres per second, a mixture flows through a channel 60 metres in length in 20 seconds. If the time required for sampling is five seconds, the tendency is towards clean water over one-quarter of the circuit at the end of the sampling operation.

To diminish this effect, it is of course possible to add a buffer reservoir of adequate capacity to the circuit; the pump suction tank always more or less achieves this buffer effect.

However, a reservoir which is large enough to permit measurement by means of a calibrated tank becomes troublesome when the installation stops 
work and a great deal of time is required to get it back into the stabilized condition required for operation.

We therefore thought it necessary to devise an instantaneous measuring instrument which conld also be used on industrial installations.

\section{PRINCTPLE OF THE INSTRUMENT}

The device used involves the contraction of the stream of liquid at the conduit outlet. At a distance upstream sufficiently short to enable head losses to be treated as negligible, a pressure is obtained in the pipe corresponding to the difference between the kinetic heads at the ontlet section and at the measurement section.

If :

$\mathrm{Q}$ is the flow to be measured;

$S$ the section of the pipe;

$s$ the contracted section at the pipe-outlet;

$\mathrm{H}=\frac{\Delta \mathrm{P}}{\bar{\omega}}$ the loss of pressure read on the pressure gauge fitted to the pressure intake, we have:

$$
\frac{\Delta \mathrm{P}}{\omega}=\frac{\mathrm{Q}^{2}}{2 !}\left(\frac{1}{\mathrm{~s}^{2}}-\frac{1}{\mathrm{~S}^{2}}\right)
$$

By reference to the mean velocity in the pipe, we have:

$$
\mathrm{H}=\frac{\Delta \mathrm{P}}{\omega}=\frac{V^{2}}{2 !}\left[\left(\frac{\mathrm{S}}{\mathrm{s}}\right)^{2}-1\right]
$$

By making $K$ the ratio of sections $\frac{s}{S}$ :

$$
\frac{\Delta \mathrm{P}}{\bar{\omega}}=\left(\frac{1}{\mathrm{~K}^{2}}-1\right) \frac{\mathrm{V}^{2}}{2 g}
$$

With the devices invented, this formula is proved and may be taken as the calibration curve in clean water. In order that this condition may be fulfilled, it is of course necessary for the shape of the convergent to be such as to prevent any separation of the liquid stream at the outlet. The instrument is shaped like a whistle (see figure 1), this facilitating its construction. Figure 2 gives in relative variables the plan of a whistle having a contraction ratio of $\mathrm{K}=0.60$.

Figure 3 gives the value measured for $\frac{\mathrm{H}}{\mathrm{V}^{2}}$ for various whistles as a function of

$$
\frac{1}{2 g}\left(\frac{1}{K^{2}}-1\right)
$$

A straight line is obtained at an angle of $45^{\circ}$. This result has been obtained as a result of calibration carried out in clean water with a Rehbock type weir or by a calibrated tank according to the value of the discharge utilized.

The pressure intake is sinilar to that used for head loss measurements. The pressure gauge consists of a simple glass tube fixed alongside a graduated rod. It may be replaced or accompanied by a recording pressure gauge.

\section{CALIBRATION OF THE FLOW-METER FOR MIXTURES.}

We have already had occasion to use this instrument during previous tests, and have foundstbject to checling - that calibration results obtained with clean water were also correct for mixtures on condition that the reading given by the flow-meter was corrected by dividing the head of clean water by the specific gravity of the mixture (transportation concentration).

We wished to check this point and, in order to do so, we undertook a series of calibration tests with the $40 \mathrm{~mm}$ diameter pipe of our transportation installation.

The installation operated in open circuit and the flow was checked by a calibrated tank. An endless belt arrangement kept the supply of solid material constant.

We carried ont two series of tests :

with the flow-meter in an horizontal position;

with the flow-meter in a vertical position.

Calmbration of the flow-Meter in the morizontal POSITION, WITH TRANSPORTATION OF MIXTURE.

The flow-meter used for the tests had previously been calibrated in clean water. The figure 4 shows the results of these tests.

The mixture tests were carried out with several types of materials, of different dimensions and specific gravities, and with different concentrations and discharges.

a) Loire sand:

a sand mixture having a mean diameter of $d n=1.50 \mathrm{~mm}$. The concentrations under consideration, expressed in true volume in \%, varied from $3.7 \%$ to $19.70 \%$ for velocities ranging from 1.40 metres per second to 2.50 metres per second.

b) Barbiére sand:

sand with a mean diameter $d n: 0.10 \mathrm{~mm}$, and 2.65 specific gravity for a concentration of $20 \%$ in true volume.

c) Fine Rhône gravel:

mean diameter $d_{n}: 5 \mathrm{~mm}$, specific gravity : 2.65; the concentrations studied were $3.98 \%$ to $16.90 \%$ in true volume.

d) Soot:

mean diameter $d n: 0.050 \mathrm{~mm}$; specific gravity : 2.24; the concentrations studied were 5.51 to $5.95 \%$ in true volume. 
e) Cast iron chips :

mean diameter dn: $4 \mathrm{~mm}$; specific gravity: 6.50 ; the concentration was $3.14 \%$ in true volume.

The results of these tests are shown in figure 5 .

It was found during these tests, for velocity corresponding to the deposit regime in the transportation pipe, that pressures measured by the pressurcgauge depended both on the depth of the deposit in the pipe and also on the discharge of the mixture.

Callibration of the Flow-meter in trme vertical, POSITION, WTTH TRANSPORTATION OF MIXTERE

We carried out similar tests with the flow-meter in the vertical position at the end of a swan-neck in order to avoid any deposit in the upstream portion of the flow-meter.

These tests were carried out with Loire, Honfleur and Barbière sands, as described in the preceding paragraph.

The results of these tests are shown in figure 6 .

\section{INTERPRETATION OF TEST RESULTS}

The readings on the pressure gauge in heads of clean water during the tests are expressed in terms of $\mathrm{V}^{2}(\mathrm{~V}=$ mean flow velocity of the mixture in the pipe) - On figures 5 and 6 the white marlss correspond to direct readings in heads of clean water.

On these graphs it can be seen that whatever the material, its diameter and its concentration during transport, the increase in pressure due to the contraction of the flow-meter depends very little on the specific gravity of the mixture, since practically all the test points appear on the calibration curve of the flow-meter in clean water.

The greatest divergency recorded corresponds to the transportation of iron chips which gives an error of $4 \%$ on the mean flow velocity.

The same graphs also show the test points (black marks) with the corrected manometric heads of the mixture's specific gravity $H=H / \delta$ (o being the specific gravity of the mixture transported). Dispersion becomes very great and all the points are then situated systematically under the calibration curve in clean water.

Be that as it may, and without entering into theoretical details regarding the mechanism of transport in the whistle-type flow-meters, we have found that, concerning tests on the transportation of sand in pipes (and based on the experiments just described), the calibrating curve for flow-meters in clean water is equally correct for the transport of solid materials, provided that the materials used are sand or other materials having a specific gravity of less than 3 . In addition, the concentrations should not exceed $20 \%$ in true volume, the conditions should be such that there is no formation of deposit upstream of whistle, and the concentration coefficient $K$ of the whistle should be such that $K \geqslant 0,5$.

It should be noted that when working with very fine materials having plastic properties, it is advisable to correct the pressure gauge reading relating to the mixture's specific gravity. However, this does not apply to sand which, after all, constitutes the principal part of natural alluvion.

We also calibrated the whistle flow-meter for deposit formation flow regimes.

In order not to overburden this report, we shall not give the results obtained herein. They have enabled us successfully to interpret the measurements made at Nantes with pipes of 580 and $700 \mathrm{~mm}$ in diameter with the aid of contraction flow-meters (fig. 7). These measurements were the subject of a communication to the Sociéte Hydrotechnique de France by Messrs. Soler and BALLADE.

The contraction flow-meter was also successfully used at Donzère for tests on the CNR 2 dredger with pebbles having diameters of up to $100 \mathrm{~mm}$ (fig. 8).

To conclude, we would state that for sand in a non-deposit flow regime, the accuracy of measurement of the discharge or of the mean velocities is very probably greater than $\pm 2 \%$.

\section{CONCLUSION}

The whistle flow-meter, which was designed for use under the very special conditions of discharge measurements in solid transportation test installations, and whose operation is based on the measurement of the pressure at the commencement of a contracted jet, behaved perfectly throughout all our experiments.

It can be incorporated with no difficulty in the most complex installation and does not adversely affect operational conditions.

Assembly and dismantling present no difficulty and it is particularly convenient to use.

The very stringent tests to which it was previously submitted and the very careful calibrations which were carried out before any model was put into service showed that, within a very wide range of concentrations and material specific gravity, and subject to some elementary precautions (deposits), the degree of accuracy obtained is very satisfactory, and is at least $\pm 2 \%$.

Finally, the design of the whistle flow-meter fulfils the twofold requirement of compliance with the laws of Hydraulics and facility of manufacture. The simplification of the instrument is not, in our opinion, the least of its advantages; its successful use, industrially, in the dredging installations at Donzère-Mondragon or at Nantes is a clear illustration. This adaptability in a laboratory instrument is sufficiently remarkable to make it well worthy of mention. 